\title{
HUKUM DALAM PERMASALAHAN PERDAGANGAN ANAK DI INDONESIA
}

\author{
Oleh: \\ Andi Rezky Aprilianty Punagi, Ishartono, \& Gigin Ginanjar Kamil Basar \\ Email: \\ rezkyaprilianty@gmail.com; ishartono@gmail.com; giginkb@yahoo.com
}

\begin{abstract}
ABSTRAK
Kebanyakan orang-orang yang menjadi korban trafficking itu miskin dan tidak cukup memiliki peluang ekonomi. Orang yang kurang pendidikan, kurang memiliki keterampilan, atau tersisih dari peluang ekonomi dikarenakan alasan-alasan lain (seperti deskriminasi) adalah pihak yang paling rentan. Perdagangan anak merupakan suatu masalah kompleks yang memerlukan pendekatan dari berbagai sisi. Pembuat undang-undang harus didesak untuk meneliti undang-undang/hukum nasionalnya secara kritis dengan maksud memperkuat atau melengkapi undang-undang tersebut akan membentuk suatu wujud perundang-undangan yang mampu melindungi anak-anak dari eksploitasi seksual dan eksploitasi ekonomi.

Anak adalah mata rantai yang sangat menentukan wujud kehidupan suatu bangsa di masa depan. Agar mampu memikul tanggung jawab tersebut maka anak perlu mendapatkan kesempatan yang seluas-luasnya dalam mewujudkan potensinya agar dapat tumbuh dan berkembang dengan wajar dan optimal baik secara jasmani, rohani dan sosialnya. Kebutuhan dasar Maslow ada lima tingkatan yaitu kebutuhan sosiologis, kebutuhan keamanan, kebutuhan sosial, kebutuhan harga diri, dan kebutuhan aktualisasi diri.

Hukum yang mengatur mengenai anak di Indonesia telah banyak dibuat. Beberapa diantaranya yaitu Undang-undang Nomor 23 Tahun 2003 tentang Perlindungan Anak merupakan peraturan khusus yang mengatur mengenai masalah anak. Dan juga adanya Undang Undang No.21 Tahun 2007 Tentang Pemberantasan Tindak Pidana Perdagangan Orang. Akan tetapi, permasalahan perdagangan anak masih belum terselesaikan dengan baik dan menyeluruh dikarenakan para pelaku kejahatan yang tidak memiliki ketakutan akan hukum yang dibuat. Maka dari itu, sudut pandang rubah tidak hanya melihat dari pelaku tetapi juga melihat dari faktor-faktor pendukung terjadinya perdagangan anak.
\end{abstract}

Kata Kunci: Anak, Perdagangan, Hukum, Undang-Undang

\section{PENDAHULUAN}

Anak merupakan harapan atau dambaan setiap orang atau keluarga. Namun dalam kenyataannya sebagaimana banyak diberitakan, masih banyak anak mendapatkan perlakuan yang tidak wajar, hak-hak anak semakin terabaikan, bahkan permasalahan anakpun semakin kompleks. Permasalahan yang menonjol antara lain anak putus sekolah, anak jalanan, anak terlantar, pekerja anak, anak-anak korban konflik bersenjata, anak-anak korban trafficking, sampai anak-anak yang dilacurkan.

Di Indonesia, akhir-akhir ini telah banyak memberitakan mengenai perdagangan anak, baik yang masih bayi, maupun yang remaja untuk dijadikan pekerja seks komersial. Contoh kasus yang menimpa 3 bayi yang menjadi korban perdagangan anak oleh salah satu yayasan yang ada di Bogor. 
Kasus yang lain yaitu yang menimpa pelajar perempuan yang baru berumur 14 dan 15 tahun yang merupakan korban perdagangan manusia dan dijadikan pekerja seks komersial.

Dalam buku "Panduan Bagi Pembuat Undang-Undang" dari Unicef, ada banyak faktor yang mendorong terjadinya trafficking dan memberi andil bagi keberhasilan jaringan kejahatan yang terlibat dalam perdagangan manusia. Kebanyakan orang-orang yang menjadi korban trafficking itu miskin dan tidak cukup memiliki peluang ekonomi. Orang yang kurang pendidikan, kurang memiliki keterampilan, atau tersisih dari peluang ekonomi dikarenakan alasan-alasan lain (seperti deskriminasi) adalah pihak yang paling rentan. Faktor-faktor ini, ditingkah dengan adanya deskriminasi jender, ras, etnis, kemiskinan dan pengangguran atau keadaan tidak aman karena konflik bersenjata, memungkinkan jaringan perdagangan manusia tumbuh subur.

Upaya-upaya pencegahan yang dirancang untuk menurunkan permintaan dan pasokan orang yang diperdagangkan harus berfokus pada faktor/akar masalah yang menyebabkan trafficking. Sementara upaya-upaya pencegahan sifatnya penegak hukum, para pembuat undang-undang dapat memanfaatkan kepemimpinan mencoba mencari akar penyebab. Dimana perundang-undangan dipandang sesuai, pembuatan undang-undang harus mengambil langkah-langkah untuk mengesahkan undang-undang yang cocok atau memperbaharui undang-undang yang ada. Dalam hal demikian, halhal berikut harus dipertimbangkan oleh para pembuat undang-undang:

- Banyak orang diperdagangkan karena kemiskinan; tekankan pada kebutuhan untuk mengidentifikasi sumber pendapatan alternative, dan penciptaan kesempatan untuk memperoleh pendapatan bagi kaum miskin. Secara khusus, wanita dan anak-anak rentan terhadap pekerjaanpekerjaan eksploitasi karena berbagai faktor seperti buruknya akses terhadap pendidikan dan lapangan kerja, dan undang-undang tentang status pribadi dan kepemilikan. Sayangnya, strategi pembangunan sering gagal untuk mencermati dimensi kemiskinan dari sudut jender, dan karenanya, mempertajam perbedaan antara pria dan wanita dalam pembangunan ekonomi.

- Anak rentan terhadap pekerjaan yang eksploitatif bila mereka dipaksa bekerja untuk memberikan tambahan pendapatan bagi keluarganya. Karena anak-anak biasanya hanya memiliki keterampilan rendah, mereka dipaksa untuk melakukan pekerjaan yang kasar dan berubah rendah atau dipaksa melakukan berbagai bentuk pekerjaan yang dieksploitatif yang mungkin menghasilkan pendapatan yang lebih tinggi untuk keluarganya.22

Perdagangan anak merupakan suatu masalah kompleks yang memerlukan pendekatan dari berbagai sisi. Pembuat undang-undang harus didesak untuk meneliti undang-undang/hukum nasionalnya secara kritis dengan maksud memperkuat atau melengkapi undang-undang tersebut akan membentuk suatu wujud perundang-undangan yang mampu melindungi anak-anak dari eksploitasi seksual dan eksploitasi ekonomi.

\section{PEMBAHASAN}

Anak adalah mata rantai yang sangat menentukan wujud kehidupan suatu bangsa di masa depan. Anak merupakan potensi sumber daya manusia sebagai penerus cita-cita bangsa yang diletakkan oleh generasi sebelumnya. Oleh karena itu, agar mampu memikul tanggung jawab tersebut maka anak perlu mendapatkan kesempatan yang seluas-luasnya dalam mewujudkan potensinya agar dapat tumbuh dan berkembang dengan wajar dan optimal baik secara jasmani, rohani dan sosialnya.

Pertama, akan dibahas terlebih dahulu mengenai kebutuhan dan hak terhadap anak. Apa yang dibutuhkan anak-anak untuk keselamatan dan perkembangan? Dengan pertanyaan tadi, pertamatama, dijelaskan terlebih dahulu mengenai hierarki kebututan.

Psikolog Abraham Maslow pertama kali memperkenalkan konsep hierarki kebutuhan di tahun 1943. Hierarki ini menunjukkan bahwa orang termotivasi untuk memenuhi kebutuhan dasar sebelum pindah ke kebutuhan lain. Hierarki kebutuhan Maslow paling sering ditampilkan sebagai sebuah

\footnotetext{
22 Unicef. "Memerangi Perdagangan Anak." Panduan Bagi Pembuat Undang-Undang.
} 
pirmida. Tingkat terendah piramida terdiri dari kebutuhan yang paling dasar, sementara kebutuhan yang paling kompleks terletak di bagian atas piramida. Kebutuhan di bagian bawah piramida merupakan persyaratan fisik dasar termasuk kebutuhan makanan, air, tidur, dan kehangatan. Setelah kebutuhan tingkat bawah ini telah terpenuhi, orang bisa melanjutkan ke tingkat kebutuhan berikutnya, yaitu untuk keselamatan dan keamanan.

Ketika orang melakukan kemajuan dalam piramida, kebutuhan semakin menjadi bersifat psikologis dan sosial. Tak lama kemudian, kebutuhan akan cinta, persahabatan dan keintiman menjadi penting. Lebih lanjut ke atas piramida, kebutuhan harga diri dan perasaan berprestasi memperoleh prioritas. Maslow menekankan pentingnya aktualisasi diri yang merupakan proses tumbuh dan berkembang sebagai seseorang untuk mencapai potensi individu.

Ada lima tingkat yang berbeda dalam hierarki kebutuhan Maslow:

1. Kebutuhan Sosiologis

Ini termasuk kebutuhan palinh dasar yang penting untuk kelangsungan hidup, seperti kebutuhan air, udara, makanan, dan tidur.

2. Kebutuhan Keamanan

Ini termasuk kebutuhan untuk keselamatan dan keamanan. Kebutuhan keamanana penting untuk kelangsungan hidup, tetapi kebutuhan ini tidak terlalu menuntut seperti kebutuhan fisiologis. Contoh kebutuhan keamanan termasuk keinginan untuk tetap kerja, pendidikan, lingkungan aman dan naungan/perlindungan dari lingkungan.

3. Kebutuhan Sosial

Ini termasuk kebutuhan untuk memiliki, cinta dan kasih saying. Maslow menganggap kebutuhan ini kurang begitu mendasar dari pada kebutuhan fisiologis dan keamanan. Hubungan seperti persahabatan, ikatan romantic dan keluarga membantu memenuhi kebutuhan akan persahabatan dan penerimaan, seperti halnya keterlibatan dalam kelompok-kelompok sosial, komunitas atau keagamaan.

4. Kebutuhan Harga Diri

Setelah tiga kebutuhan yang pertama telah terpenuhi, kebutuhan harga diri menjadi semakin penting. Ini termasuk kebutuhan untuk hal-hal yang mencerminkan tentang harga diri, nilai pribadi, pengakuan sosial dan prestasi.

5. Kebutuhan Aktualisasi diri

Ini adalah tingkat tertinggi dari hierarki kebutuhan Maslow. Orang yang mengaktualisasikan dirinya adalah orang yang sadar diri, peduli dengan pertumbuhan pribadi, kurang peduli dengan pendapat orang lain dan tertarik untuk memebuhi potensi mereka.23

Menurut Justika (2002), ada 4 hak anak yang telah disesuaikan dengan konvensi hak anak PBB tahun 1989 yaitu:

a. Hak kelangsungan hidup (survival right) adalah hak untuk memperoleh pelayanan kesehatan terbaik, sehingga terhindar dari beberapa penyakit infeksi yang mematikan.

b. Hak berkembang (development right) bahwa pemberian gizi dan pendidikan yang baik serta lingkungan sosial budaya yang memungkinkan anak berkembang sebagai manusia dewasa yang beridentitas dan bermartabat.

c. Hak memperoleh perlindungan (protection right) yaitu memperoleh perlindungan dari berbagai deskriminasi dari tindak kekerasan baik oleh warna kulit, ideology, politik, agama maupun kondisi fisik.

d. Hak untuk berpartisipasi dalam berbagai keputusan yang menyangkut kepentingan hidupnya. (Justika, S.B. 2002: 29)

\footnotetext{
${ }^{23}$ Mallon, Gerald P. dan Joan Morse. 2012. Modul Latihan Pekerjaan Sosial Berpusat pada Anak dan Keluarga.

"Perlindungan Anak dan Perencanaan Permanensi." Save The Children, Jakarta
} 
Pertanyaan selanjutnya yang akan dibahas adalah mengenai masalah apa yang terjadi sehingga mengakibatkan masih banyak dan maraknya perdagangan anak yang terjadi di Indonesia.

Undang-undang Nomor 23 Tahun 2003 tentang Perlindungan Anak merupakan peraturan khusus yang mengatur mengenai masalah anak. Tujuan dari perlindungan anak sendiri disebutkan dalam Pasal 3 UU No. 23/ 2003: "Perlindungan anak bertujuan untuk menjamin terpenuhinya hakhak anak agar dapat hidup, tumbuh, berkembang, dan berpartisipasi secara optimal sesuai dengan harkat dan martabat kemanusiaan, serta mendapat perlindungan dari kekerasan dan diskriminasi, demi terwujudnya anak Indonesia yang berkualitas, berakhlak mulia, dan sejahtera." Dan juga adanya Undang Undang No.21 Tahun 2007 Tentang Pemberantasan Tindak Pidana Perdagangan Orang "Perdagangan Orang adalah tindakan perekrutan, pengangkutan,penampungan, pengiriman, pemindahan, atau penerimaan seseorangdengan ancaman kekerasan, penggunaan kekerasan, penculikan,penyekapan, pemalsuan, penipuan, penyalahgunaan kekuasaan atauposisi rentan, penjeratan utang atau memberi bayaran atau manfaat,sehingga memperoleh persetujuan dari orang yang memegang kendali atasorang lain tersebut, baik yang dilakukan di dalam negara maupun antarnegara, untuk tujuan eksploitasi atau mengakibatkan orang tereksploitasi."

Dengan adanya peraturan tersebut, menyiratkan keinginan negara untuk memberikan perlindungan dan juga pengamanan bagi generasi bangsa yang akan datang yang merupakan penerus dalam memajukan bangsa dan memberi bukti adanya perhatian pemerintah untuk melindungi hakhak anak dan menjamin serta melindungi masa depan anak. Tetapi, kenyataan yang terjadi adalah masih banyak kasus-kasus anak yang menjadi korban perdagangan manusia di Indonesia.

Hukum telah menjadi salah satu harapan yang diberikan pemerintah untuk menaggulangi permasalahan perdagangan anak. Akan tetapi, banyaknya pemberitaan di media masa mengenai kasus perdagangan anak menunjukkan bahwa Undang-Undang yang telah ada dan telah dibuat masih belum efektif dalam menangani dan memberantas perdagangan anak.

Permasalahan perdagangan anak merupakan permasalahan yang komplek yang mengakibatkan sulit untuk ditanggulangi oleh hukum disebabkan Perdagangan anak merupakan kejahatan dengan modus yang bermacam-macam serta terorganisir dengan rapi pada umumnya, juga kejahatan ini terorganisir sampai keluar negeri sehingga menyulitkan para penegak hukum untuk menyelesaikan permasalahan ini. Semua pasal yang dituangkan dalam undang-undang tidak membuat para pelaku menjadi ketakutan, tetapi menciptakan modus baru dalam perdagangan anak. Para pelaku kejahatan perdagangan anak bisanya melakukan berbagai macam modus seperti penculikan, pemalsuan identitas, iming-iming pekerjaan, dan lain sebagainya. Pemimpin dari kejahatan ini belum dapat diungkap oleh hukum, sehingga hukum dirasa belum efektif untuk menanggulangi permasalahan perdagangan anak ini.24

\section{PENUTUP}

Anak adalah mata rantai yang sangat menentukan wujud kehidupan suatu bangsa di masa depan. Anak merupakan potensi sumber daya manusia sebagai penerus cita-cita bangsa yang diletakkan oleh generasi sebelumnya. Oleh karena itu, agar mampu memikul tanggung jawab tersebut maka anak perlu mendapatkan kesempatan yang seluas-luasnya dalam mewujudkan potensinya agar dapat tumbuh dan berkembang dengan wajar dan optimal baik secara jasmani, rohani dan sosialnya. Anak merupakan harapan atau dambaan setiap orang atau keluarga. Namun dalam kenyataannya sebagaimana banyak diberitakan, masih banyak anak mendapatkan perlakuan yang tidak wajar, hakhak anak semakin terabaikan, bahkan permasalahan anakpun semakin kompleks.

\footnotetext{
${ }^{24}$ Markus Tampubolon dalam Makalah “Efektivitas Hukum Dalam Menanggulangi Permasalahan Perdagangan Anak Di Indonesia".
} 
Dari penjabaran di atas, maka penulis dapat menyimpulkan bahwa adanya hukum serta Undang-Undang yang secara jelas menentang adanya perdagangan anak tidak menjadikan pelaku kejahatan jera dan merasa takut, serta tidak menjadikan permasalahan perdagangan anak terselesaikan.

Faktor utama yang menyebabkan terjadinya perdagangan anak adalah kemiskinan serta pendidikan yang relatif rendah. Kebanyakan orang-orang yang menjadi korban trafficking itu miskin dan tidak cukup memiliki peluang ekonomi. Orang yang kurang pendidikan, kurang memiliki keterampilan, atau tersisih dari peluang ekonomi dikarenakan alasan-alasan lain (seperti deskriminasi) adalah pihak yang paling rentan. Faktor-faktor ini, ditingkah dengan adanya deskriminasi jender, ras, etnis, kemiskinan dan pengangguran atau keadaan tidak aman karena konflik bersenjata, memungkinkan jaringan perdagangan manusia tumbuh subur. Maka dari itu, upaya-upaya yang dibutuhkan harus melihat dan mengintervensi lebih dulu faktor-faktor penyebab perdagangan anak, seperti untuk masalah kemiskinan, pemerintah dapat memberikan lapangan pekerjaan bagi para orang tua, serta keterampilan-keterampilan yang akan berguna kelak untuk rakyat miskin. Untuk pendidikan sendiri, bisa melalui bantuan operasional sekolah serta akses sekolah murah. Tetapi, upaya-upaya tersebut tidak akan berjalan dengan semestinya dan tidak akan berjalan dengan baik jika tidak didukung dan tidak adanya partisipasi dan kerjasama dari masyarakatnya. Permasalahan perdagangan anak tidak sepenuhnya urusan pemerintah tetapi juga banyak pihak yang ikut andil seperti masyarakat serta LSM yang menangani permasalahan anak.

Intervensi sosial dapat diartikan sebagai cara untuk strategi pemberian bantuan kepada masyarakat. Intervensi sosial merupakan metode yang digunakan dalam praktik di lapangan pada bidang pekerjaan sosial dan kesejahteraan sosial. Pekerjaan sosial dan kesejahteraan sosial adalah dua bidang yang bertujuan meningkatkan kesejahteraan seseorang melalui upaya memfungsikan kembali fungsi sosialnya. Keberfungsian sosial menunjuk pada kondisi di mana seseorang dapat berperan sebagaimana seharusnya sesuai dengan harapan lingkungan dan peran yang dimilikinya. 25

Pekerja sosial pada masalah ini sangat memiliki andil dalam penyelesaian masalah. Pekerja sosial selain menjadi profesi yang memahami mengenai intervensi, juga dapat menjadi educator dalam memberikan penyuluhan tentang perdagangan anak, dapat menjadi bagian dalam pembuatan ataupun perbaikan dalam Undang-Undang, serta kerjasama dengan pihak LSM yang menangani permasalahan anak.

\section{DAFTAR PUSTAKA}

Ikawati. 2007. Pengkajian Model Pemberdayaan Lembaga Perlindungan Anak Dalam Pelayanan Kesejahteraan Anak. Departemen Sosial RI, Yogyakarta.

Mallon, Gerald P. dan Joan Morse. 2012. Modul Latihan Pekerjaan Sosial Berpusat pada Anak dan Keluarga. Perlindungan Anak Dan Perencanaan Permanensi. Save The Children, Jakarta

Unicef. Memerangi Perdagangan Anak. Panduan Bagi Pembuat Undang-Undang

Sumber Lain

Tampubolon, Markus. 2012. Efektivitas Hukum Dalam Menanggulangi Permasalahan Perdagangan Anak Di Indonesia.

http://id.wikipedia.org/wiki/Intervensi_sosial

\footnotetext{
${ }^{25}$ http://id.wikipedia.org/wiki/Intervensi_sosial
} 